\title{
Sheep manure application increases soil exchangeable base cations in a semi-arid steppe of Inner Mongolia
}

\author{
YuGe ZHANG ${ }^{1,2}$, Shan YANG ${ }^{1,2}$, MingMing FU ${ }^{1,3}$, JiangPing CAI ${ }^{1,3}$, YongYong ZHANG ${ }^{1,3}$, \\ RuZhen WANG ${ }^{1,3}$, ZhuWen $\mathrm{XU}^{1}$, YongFei BAI ${ }^{4}$, Yong JIANG ${ }^{1 *}$ \\ ${ }^{1}$ State Key Laboratory of Forest and Soil Ecology, Institute of Applied Ecology, Chinese Academy of Sciences, Shenyang \\ 110016, China; \\ ${ }^{2}$ Key Laboratory of Regional Environment and Eco-remediation, College of Environment, Shenyang University, Shenyang \\ 110044, China; \\ ${ }^{3}$ University of Chinese Academy of Sciences, Beijing 100049, China; \\ ${ }^{4}$ State Key Laboratory of Vegetation and Environmental Change, Institute of Botany, Chinese Academy of Sciences, Beijing \\ 100093, China
}

\begin{abstract}
The long-term productivity of a soil is greatly influenced by cation exchange capacity (CEC). Moreover, interactions between dominant base cations and other nutrients are important for the health and stability of grassland ecosystems. Soil exchangeable base cations and cation ratios were examined in a 11-year experiment with sheep manure application rates $0-1,500 \mathrm{~g} /\left(\mathrm{m}^{2} \cdot \mathrm{a}\right)$ in a semi-arid steppe in Inner Mongolia of China, aiming to clarify the relationships of base cations with soil $\mathrm{pH}$, buffer capacity and fertility. Results showed that CEC and contents of exchangeable calcium $\left(\mathrm{Ca}^{2+}\right)$, magnesium $\left(\mathrm{Mg}^{2+}\right)$, potassium $\left(\mathrm{K}^{+}\right)$and sodium $\left(\mathrm{Na}^{+}\right)$were significantly increased, and $\mathrm{Ca}^{2+}$ saturation tended to decrease, while $\mathrm{K}^{+}$saturation tended to increase with the increases of sheep manure application rates. The $\mathrm{Ca}^{2+} / \mathrm{Mg}^{2+}$ and $\mathrm{Ca}^{2+} / \mathrm{K}^{+}$ratios decreased, while $\mathrm{Mg}^{2+}, \mathrm{K}^{+}$and $\mathrm{Na}^{+}$saturations increased with increasing manure application rates. Both base cations and CEC were significantly and positively correlated with soil organic carbon (SOC) and soil pH. The increases of SOC and soil pH would be the dominant factors that contribute to the increase of cations in soil. On a comparison with the initial soil pH before the experiment, we deduced that sheep manure application could partly buffer soil $\mathrm{pH}$ decrease potentially induced by atmospheric deposition of nitrogen and sulfur. Our results indicate that sheep manure application is beneficial to the maintenance of base cations and the buffering of soil acidification, and therefore can improve soil fertility in the semi-arid steppes of northeastern China.
\end{abstract}

Keywords: base cation; sheep manure; soil pH; soil fertility; buffer capacity; grassland conservation

Citation: YuGe ZHANG, Shan YANG, MingMing FU, JiangPing CAI, YongYong ZHANG, RuZhen WANG, ZhuWen XU, YongFei BAI, Yong JIANG. 2015. Sheep manure application increases soil exchangeable base cations in a semi-arid steppe of Inner Mongolia. Journal of Arid Land, 7(3): 361-369. doi: 10.1007/s40333-015-0004-5

Soil fertility depends largely on soil's capacity in adsorbing and releasing exchangeable base cations to plants, as well as its retention against leaching. The interactions between soil exchange properties and other physical, chemical and biological properties control nutrient availability of both higher plants and microorganisms (Havlin et al., 2004; Brady and Weil, 2007; Jiang et al., 2009), and hence these interactions are important for the health and stability of terrestrial ecosystems (Lucas et al., 2011). For example, the calcium saturation in soil should approach or even exceed $80 \%$ for calcium-loving plants such as alfalfa (Brady and Weil, 2007).

Cation exchange capacity (CEC), cation ratios and base saturations in soils are closely related to parent materials and biogeochemical processes, and deeply affected by anthropogenic activities, such as fertilization, irrigation and reconstruction of plants, in terrestrial

*Corresponding author: Yong JIANG (E-mail: jiangyong@iae.ac.cn)

Received 2014-06-28; revised 2014-10-15; accepted 2015-01-19

(C) Xinjiang Institute of Ecology and Geography, Chinese Academy of Sciences, Science Press and Springer-Verlag Berlin Heidelberg 2015 
ecosystems (Jiang et al., 2005a; Zhang et al., 2013). In arid and semi-arid regions where $\mathrm{pH}$ values in surface soil usually greater than 7 and exchangeable $\mathrm{Al}^{3+}$ and $\mathrm{H}^{+}$are negligible, CECs are essentially $100 \%$ saturated with exchangeable nonacid cations $\mathrm{Ca}^{2+}, \mathrm{Mg}^{2+}$, $\mathrm{K}^{+}$and $\mathrm{Na}^{+}$, while in warm and humid regions, CECs saturated by these nonacid cations could be lower than 25\% (Brady and Weil, 2007; Zhang et al., 2013). The increase in soil organic matter (SOM) would increase the base cations and CEC through its enhancement on available negative charges, which in turn increase the buffer capacity in soil (Havlin et al., 2004; Brady and Weil, 2007). Consequently, SOM build-up usually increases soil fertility by providing essential nutrients, enhancing soil biodiversity and improving soil productivity (Jiang et al., 2007; Fu et al, 2012; Chen et al., 2013; Zhang et al., 2013). It is expected that the increase in SOM with long-term manure application would be a main pathway for improving exchangeable base cations and CEC in soil. Different manures may have different cation contents and $\mathrm{pH}$ values, and cause different responses to soil cation changes. Moreover, a same kind of manure will have different effects on soil exchange properties in different ecosystems (Edmeades, 2003; Marschner and Rengel, 2007). However, little information is available on soil exchange properties related to sheep manure application on grasslands, especially in semi-arid steppes.

The magnitude of soil $\mathrm{pH}$ changes, to some extent, depends on soil buffering capacity: for soils with $\mathrm{pH}$ $\left(\mathrm{H}_{2} \mathrm{O}\right)$ higher than $7.5, \mathrm{pH}$ is mainly buffered by calcium carbonates, as well as calcium, magnesium and potassium oxides; at intermediate $\mathrm{pH}$ levels (4.5-7.5), exchangeable base cations, soil organic matter (SOM), and mineral weathering help to buffer the soil; at acidic $\mathrm{pH}(<4.5)$, aluminum oxides and iron hydroxides act as buffering agents (Havlin et al., 2004; Brady and Weil, 2007). The above-mentioned relationships between the buffering systems and soil $\mathrm{pH}$ would show a large variation, depending on soils with different parent material (Jiang et al., 2005a), organic matter content (Oorts et al., 2003), soil particle sizes (van Erp et al., 2001) and some other pedogenic and anthropogenic conditions (Jiang et al., 2005b; Zhang et al., 2013). Some studies found that base cations and soil organic carbon (SOC) are important factors in buffering soil $\mathrm{pH}$ in the semi-arid grasslands in Inner Mongolia (Chen et al., 2013; Zhang et al., 2013). However, the dependence of base cations on SOM is heavily impacted by soil acidity, which causes the release of ions from SOM to the soil solution (Marschner and Rengel, 2007). In semi-arid grassland ecosystems, it is still not clear for the effects of manure amendment on soil acidity and the relationship between soil $\mathrm{pH}$ and base cations.

In grasslands of northeastern China, substantial land use change and ecosystem degradation have occurred over the past decades, with significant ecological consequences locally and regionally (Han et al., 2009). For example, Yang et al. (2012) reported that soil $\mathrm{pH}$ value in the surface layer declined by 0.67 in typical grasslands of northern China during 1980s2000s, which might attribute to the increases of atmospheric $\mathrm{N}$ deposition. The rate of nitrogen deposition was estimated to $5.2-18.7 \mathrm{~kg} \mathrm{~N} /\left(\mathrm{hm}^{2} \cdot \mathrm{a}\right)$ across the study area during this period. During the acidification process, base cations (e.g. $\mathrm{Ca}^{2+}, \mathrm{Mg}^{2+}$ and $\mathrm{K}^{+}$) of soil released on its surface, and exchanged with $\mathrm{H}^{+}$ (Bowman et al., 2008). The underlying mechanisms of $\mathrm{pH}$-decline are associated with base cation depletion or leaching (Lieb et al., 2011; Chen et al., 2013). However, in the semi-arid grasslands of northeastern China, the annual precipitation is comparatively low and the leaching effect is not as strong as in the humid or farmland ecosystems (Xu et al., 2014; Wang et al., 2015), and hence the potential $\mathrm{pH}$-decline in these regions should pay more attention on cation dynamics in soils. The aims of this study were to examine the changes in soil exchangeable base cations and cation ratios in an 11-year experiment with different sheep manure application rates in a semi-arid steppe of Inner Mongolia, and to address the relationships of cation properties with SOC and soil $\mathrm{pH}$.

\section{Materials and methods}

\subsection{Study area}

The field experiment was conducted at the Inner Mongolia Grassland Ecosystem Research Station (IMGERS), Chinese Academy of Sciences, located in the Xilin River Basin, Inner Mongolia autonomous region of China $\left(43^{\circ} 33^{\prime} \mathrm{N}, 116^{\circ} 40^{\prime} \mathrm{E}\right)$. It is located in a 
semi-arid continental temperate monsoon zone. The annual mean temperature is $0.3^{\circ} \mathrm{C}$, with monthly mean temperature from $-21.6^{\circ} \mathrm{C}$ in January to $19.0^{\circ} \mathrm{C}$ in July. The mean annual precipitation is $346 \mathrm{~mm}$, with about $70 \%$ occurring from May to August. The soil is originated from loess-like parent material, and is classified as dark chestnut soil, and also Haplic Kastanozems in FAO-UNESCO Soil Taxonomy (FAO, 1988). The plant community is dominated by Leymus chinensis, Stipa gradis, Agropyron cristatum and Cleistogenes squarrosa (Fu et al., 2012).

\subsection{Sheep manure application experiment and soil samplings}

In April 2000, an experiment of sheep manure application was established. Totally, 81 plots with an individual area of $5 \mathrm{~m} \times 5 \mathrm{~m}$ per plot were laid out in a randomized block design, with 1-m walkway to separate blocks and plots. Nine treatments with dry sheep manure application rates from 0 to $1,500 \mathrm{~g} /\left(\mathrm{m}^{2} \cdot \mathrm{a}\right)$ were replicated 9 times. Sheep manure with water content $40 \%-50 \%$ had been broadcasted in the raining season (July) each year. The organic matter content in dry sheep manure was $24.0 \%-27.0 \%$, nitrogen content $7.0-8.0 \mathrm{~g} / \mathrm{kg}$, and total $\mathrm{Ca}, \mathrm{Mg}, \mathrm{K}, \mathrm{Na}$ contents averaged $11.39,6.02,9.18$ and $0.07 \mathrm{~g} / \mathrm{kg}$, respectively. Before the experiment was established, soil $\mathrm{pH}$ averaged about 7.23, and soil sand, silt and clay contents were $79.18 \%, 18.85 \%$ and $2.97 \%$, respectively.

In October 2010, we selected five replicates of five treatments, with sheep manure application rates $0\left(\mathrm{M}_{0}\right)$, $50\left(\mathrm{M}_{1}\right), 250\left(\mathrm{M}_{2}\right), 750\left(\mathrm{M}_{3}\right)$ and 1,500 $\mathrm{g} /\left(\mathrm{m}^{2} \cdot \mathrm{a}\right)\left(\mathrm{M}_{4}\right)$. Soil samples were taken from the surface to a depth of $10 \mathrm{~cm}$. For each plot, five cores were collected by using a 3-cm soil auger and mixed as a composite sample. All soil samples were air-dried and ground to pass through 2-mm and 1-mm sieves for related chemical analysis.

\subsection{Chemical analyses}

Soil exchangeable cations of $\mathrm{Ca}^{2+}, \mathrm{Mg}^{2+}, \mathrm{K}^{+}$and $\mathrm{Na}^{+}$ were extracted with $1 \mathrm{M} \mathrm{NH} \mathrm{NAc}_{4} \mathrm{Ot} \mathrm{pH}=7$. The extracts were then analyzed for exchangeable $\mathrm{Ca}^{2+}, \mathrm{Mg}^{2+}, \mathrm{K}^{+}$ and $\mathrm{Na}^{+}$by flaming emission at the wavelengths of 422.7, 285.2, 766.5 and $589.0 \mathrm{~nm}$, respectively, using atomic absorption spectrophotometer (AAS, Shimadzu, Japan). Cation exchange capacity (CEC) was calculated by adding up the total amount of exchangeable $\mathrm{Ca}^{2+}$, $\mathrm{Mg}^{2+}, \mathrm{K}^{+}$and $\mathrm{Na}^{+}$, with the sum of which accounting for more than $99 \%$ of the CEC (Chen et al., 2013). Base saturation (\%) was calculated by dividing the charge equivalents of base cations by CEC and then multiplying by 100 . Soil pH was measured with combined electrodes in a 1:2.5 soil:water suspension. After soil samples were pretreated with $0.1 \mathrm{M} \mathrm{HCl}$ to neutralize carbonates, soil organic $\mathrm{C}$ was determined by the dry combustion method using a Vario ELIII Elemental Analyzer (Germany).

\subsection{Statistical analysis}

One-way ANOVA followed by least significant difference was used to test the sum of squares between and within groups, and Duncan's pairwise comparison for means separation. The significance level was set as $P<0.05$. Simple correlation coefficients and linear regression analysis were used to analyze the relationships between cations and soil chemical properties. All analyses were carried out by SPSS Version 11.5 for Windows.

\section{Results}

\subsection{Soil exchange properties under different ma- nure application rates}

Soil exchangeable cations, CEC and base saturations varied significantly under different sheep manure application rates $\left(P<0.01\right.$; Fig. 1). Soil exchangeable $\mathrm{Ca}^{2+}$, $\mathrm{Mg}^{2+}, \mathrm{K}^{+}, \mathrm{Na}^{+}$and $\mathrm{CEC}$ had highest values under the treatment with the highest manure application rate $\left(\mathrm{M}_{4}\right.$, $\left.1,500 \mathrm{~g} /\left(\mathrm{m}^{2} \cdot \mathrm{a}\right)\right)$. Such variables were greater in treatment $\mathrm{M}_{3}$ than in treatments with lower manure application rates. There was no significant difference between treatment $\mathrm{M}_{1}$ and $\mathrm{M}_{2}$ for $\mathrm{CEC}$ and base cations, except exchangeable $\mathrm{K}^{+}$. As compared with $\mathrm{M}_{0}$ treatment, soil exchangeable base cations increased by $30 \%$ for $\mathrm{Ca}^{2+}, 71 \%$ for $\mathrm{Mg}^{2+}, 200 \%$ for $\mathrm{K}^{+}, 101 \%$ for $\mathrm{Na}^{+}$and $38 \%$ for CEC at the highest input of sheep manure treatment $\mathrm{M}_{4}$ (Fig. 1).

Exchangeable $\mathrm{Ca}^{2+} / \mathrm{Mg}^{2+}$ ratio was significantly lower in treatment $\mathrm{M}_{4}$ than in the other four treatments. Exchangeable $\mathrm{Ca}^{2+} / \mathrm{K}^{+}$ratio was significantly higher in treatments $\mathrm{M}_{0}$ and $\mathrm{M}_{1}$ than in treatments with higher manure application rates. $\mathrm{K}^{+} / \mathrm{Na}^{+}$ratio was higher 

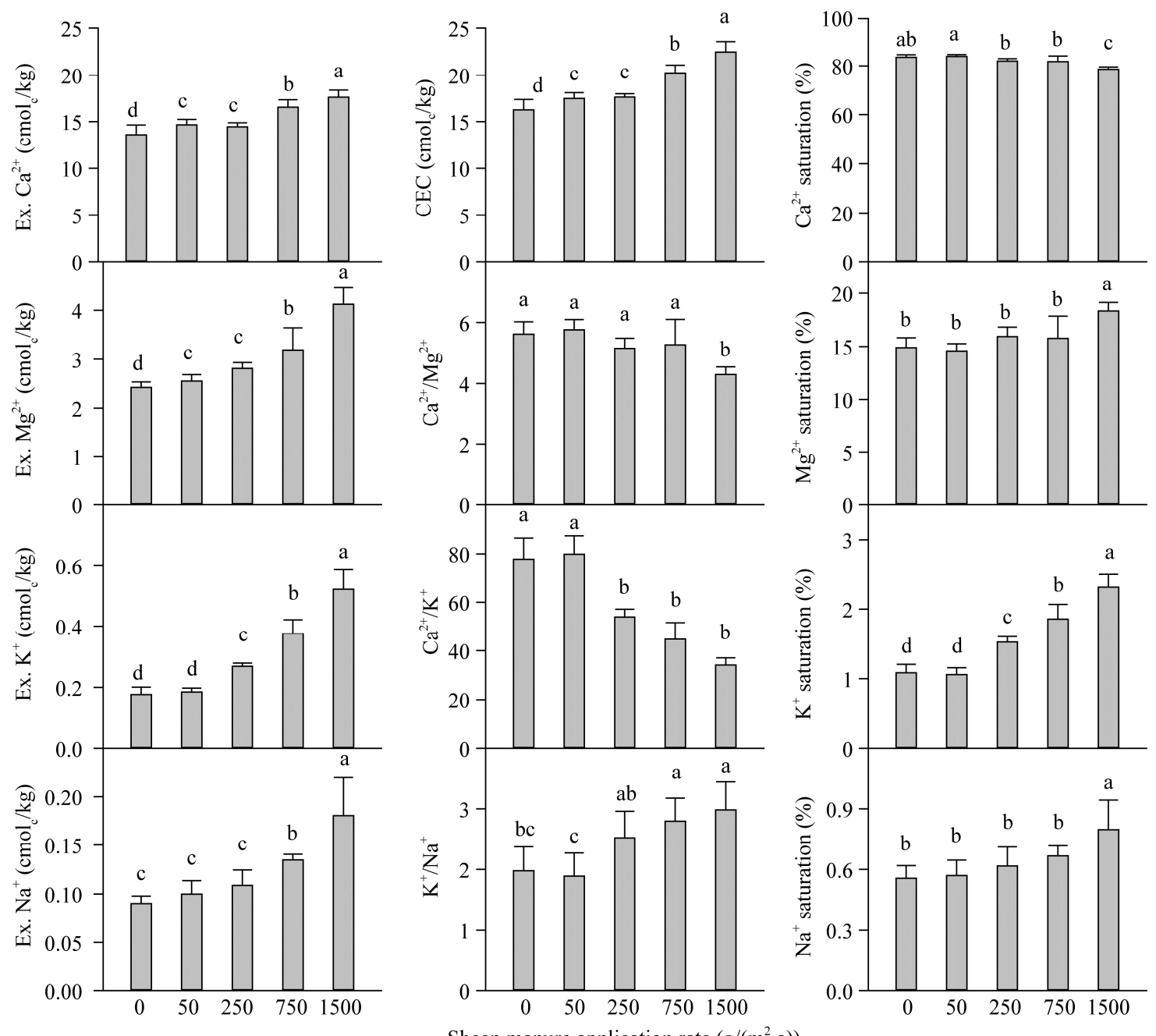

Fig. 1 Exchangeable base cations, cation exchange capacity (CEC), cation ratios and base saturations in soils under different sheep manure application rates. Different lowercase letters in the same column represent significant difference at $P<0.05$ level among different manure application rates. Ex. is an abbreviation for exchangeable.

in treatments of higher application rates (Fig. 1). Exchangeable $\mathrm{Ca}^{2+}$ saturation was significantly lower and $\mathrm{Mg}^{2+}, \mathrm{K}^{+}$, and $\mathrm{Na}^{+}$saturations were higher in treatment $\mathrm{M}_{4}$ than in other treatments. There was no significant difference for $\mathrm{K}^{+}$saturation between treatments $\mathrm{M}_{0}$ and $\mathrm{M}_{1}$, but it was significantly increased with the increasing rates of sheep manure application (Fig. 1).

\subsection{Relationships between base cations and CEC with different manure application rates, soil pH and SOC}

Soil exchange properties were positively correlated with the rates of manure inputs, soil $\mathrm{pH}$ and SOC (Fig. 2). Moreover, sheep manure application rates, soil $\mathrm{pH}$ and SOC were all negatively correlated with $\mathrm{Ca}^{2+} / \mathrm{Mg}^{2+}$,
$\mathrm{Ca}^{2+} / \mathrm{K}^{+}$and $\mathrm{Ca}^{2+}$ saturation, but positively with $\mathrm{K}^{+} / \mathrm{Na}^{+}$, and $\mathrm{Mg}^{2+}, \mathrm{K}^{+}$and $\mathrm{Na}^{+}$saturations (Table 1).

Linear regression equations (Eqs. 1-5) could be developed taking CEC or a base cation as dependent variable and both $\mathrm{pH}$ and $\mathrm{SOC}$ as independent variables, with a higher determination coefficient.

$$
\mathrm{CEC}=2.604 \mathrm{pH}+0.407 \mathrm{SOC}-9.867\left(R^{2}=0.906\right. \text {, }
$$

$$
P<0.001) \text {, }
$$

Ex. $\mathrm{Ca}^{2+}=1.362 \mathrm{pH}+0.309 \mathrm{SOC}-1.873\left(R^{2}=0.836\right.$,

$$
P<0.001) \text {, }
$$

Ex. $\mathrm{Mg}^{2+}=1.033 \mathrm{pH}+0.072$ SOC $-6.285\left(R^{2}=0.848\right.$,

$$
P<0.001) \text {, }
$$

Ex. $\mathrm{K}^{+}=0.165 \mathrm{pH}+0.021 \mathrm{SOC}-1.399\left(R^{2}=0.885\right.$, $P<0.001)$,

Ex. $\mathrm{Na}^{+}=0.043 \mathrm{pH}+0.005 \mathrm{SOC}-0.310\left(R^{2}=0.727\right.$, $P<0.001)$. 

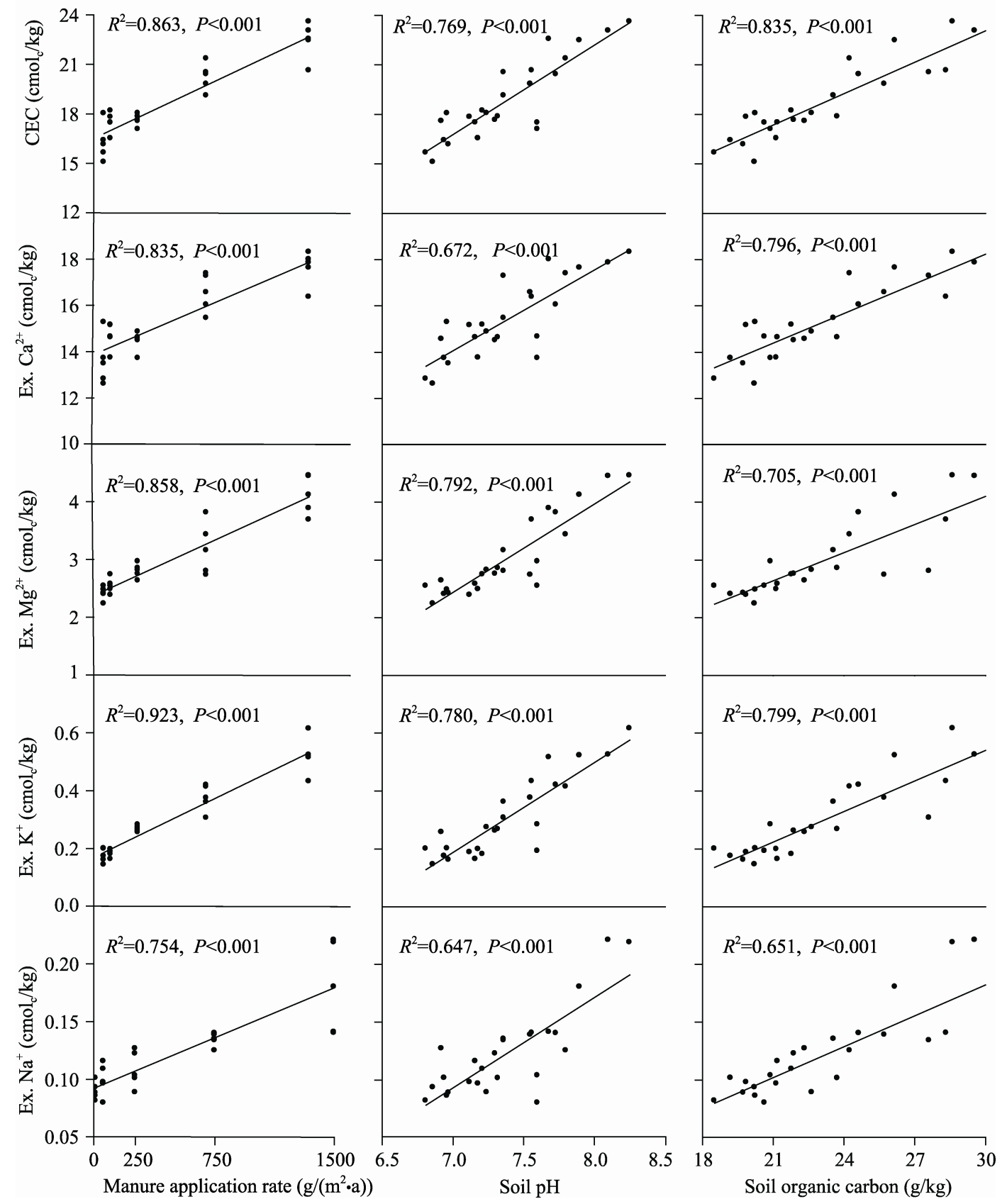

Fig. 2 Linear regressions of exchangeable base cations with sheep manure application rates, soil $\mathrm{pH}$ and soil organic carbon $(n=25)$

Table 1 Correlations of cation ratios and base saturation with different sheep manure application rates, soil pH and soil organic carbon ( $n=25)$

\begin{tabular}{lcrc}
\hline & Manure application rate & Soil $\mathrm{pH}$ & Soil organic carbon \\
\hline $\mathrm{Ca}^{2+} / \mathrm{Mg}^{2+}$ & -0.717 & -0.699 & -0.577 \\
$\mathrm{Ca}^{2+} / \mathrm{K}^{+}$ & -0.864 & -0.785 & -0.805 \\
$\mathrm{~K}^{+} / \mathrm{Na}^{+}$ & 0.681 & 0.635 & 0.633 \\
$\mathrm{Ca}^{2+}$ saturation & -0.816 & -0.783 & -0.685 \\
$\mathrm{Mg}^{2+}$ saturation & 0.732 & 0.720 & 0.589 \\
$\mathrm{~K}^{+}$saturation & 0.936 & 0.853 & 0.857 \\
$\mathrm{Na}^{+}$saturation & 0.729 & 0.648 & 0.668 \\
\hline
\end{tabular}

Note: sheep manure application rates were $0,50,250,750$ and $1,500 \mathrm{~g} /\left(\mathrm{m}^{2} \bullet \mathrm{a}\right)$, respectively. All of the coefficients are significant at $P<0.01$. 
The above equations showed that the increase of CEC or each base cation accompanied with the increase of both $\mathrm{pH}$ and SOC. According to Eq. 1, the CEC was $407 \mathrm{cmol}_{\mathrm{c}} / \mathrm{kg}$ per unit SOC, and it increased by $2.60 \mathrm{cmol}_{\mathrm{c}} / \mathrm{kg}$ as $\mathrm{pH}$ value increased by 1 .

The increases in SOC content $(\mathrm{g} / \mathrm{kg})$ and soil $\mathrm{pH}$ were in accordance with the increasing application rates of sheep manure $\left(\mathrm{SM}, \mathrm{g} /\left(\mathrm{m}^{2} \cdot \mathrm{a}\right)\right)$, and this could also be expressed with linear regression equations (Eqs. 6 and 7).

$$
\begin{aligned}
& \mathrm{SOC}=0.0057 \mathrm{SM}+20.428\left(R^{2}=0.879, P<0.001\right), \\
& \text { Soil pH=0.0006SM+7.0941 }\left(R^{2}=0.675, P<0.01\right) .
\end{aligned}
$$

\section{Discussion}

\subsection{Responses of soil exchangeable base cations and cation ratios to manure application}

The results showed that all the 4 base cations and CEC increased with the increasing input of sheep manure (Fig. 2). Equation 6 showed that SOC increased with the increasing manure application rates for 11 years. The total $\mathrm{Ca}^{2+}, \mathrm{Mg}^{2+}, \mathrm{K}^{+}$and $\mathrm{Na}^{+}$contents with the sheep manure applied averaged 11.39, $6.02,9.18$, and $0.07 \mathrm{~g} / \mathrm{kg}$, respectively. Manure application led to the accumulation of SOM and the redistribution of base cations. Thus, the increases in CEC and base cations may attribute to the added manure itself and the corresponding increases in SOM. A considerable number of studies concerning long-term fertility trials pointed out that soil organic material applications increased SOC stock and, therefore, increased CEC (Diacono and Montemurro, 2010). The evidence from 14 long-term trials worldwide showed that the use of manures relative to fertilizers could result in excessively enrichment of $\mathrm{K}^{+}, \mathrm{Ca}^{2+}$ and $\mathrm{Mg}^{2+}$ in the topsoil (Edmeades, 2003). Lax (1991) found that in calcareous soils with low clay content, both sheep and chicken manure additions significantly increased soil CEC in a 3-year study. In acid soils, the extent of increases in CEC with organic materials incorporated with soil is more remarkable (Rodella et al., 1995).

Although no statistical differences were observed for $\mathrm{Ca}^{2+}, \mathrm{Mg}^{2+}$ and $\mathrm{Na}^{+}$saturations among $\mathrm{M}_{0}$ to $\mathrm{M}_{3}$ treatments, $\mathrm{Ca}^{2+}$ saturation tended to decrease, while $\mathrm{Mg}^{2+}, \mathrm{K}^{+}$and $\mathrm{Na}^{+}$saturations tended to increase with increasing sheep manure application rates. This tendency was also reflected by calculating cation ratios: $\mathrm{Ca}^{2+} / \mathrm{Mg}^{2+}$ and $\mathrm{Ca}^{2+} / \mathrm{K}^{+}$decreased while $\mathrm{K}^{+} / \mathrm{Na}^{+}$increased with manure application (Fig. 1). Cation ratio changes showed that sheep manure application could induce the redistribution and retention of base cations. Soils in arid and semi-arid regions generally have very high levels of total $\mathrm{Ca}^{2+}$ and occupying $75 \%-85 \%$ of the $\mathrm{CEC}$ sites. In this study, $\mathrm{Ca}^{2+}$ saturation was $83.46 \%$ in $\mathrm{M}_{0}$, and decreased significantly in $\mathrm{M}_{4}$ treatment $(78.56 \%)$. Hydrated $\mathrm{K}^{+}$is weakly held relative to $\mathrm{Ca}^{2+}$ and $\mathrm{Mg}^{2+}$, therefore, $\mathrm{K}^{+}$is more readily exchangeable than $\mathrm{Ca}^{2+}$ or $\mathrm{Mg}^{2+}$ (Marschner and Rengel, 2007). However, $\mathrm{K}^{+}$content was about $9.18 \mathrm{~g} / \mathrm{kg}$ in the sheep manure applied, and the comparatively higher content of $\mathrm{K}^{+}$in manure was regarded as the driving force to improve $\mathrm{K}^{+}$saturations with increasing manure application rates (Fig. 1). Our results also verified that $\mathrm{K}^{+}$saturation, and $\mathrm{K}^{+} / \mathrm{Ca}^{2+}$ and $\mathrm{K}^{+} / \mathrm{Na}^{+}$ ratios were significantly and positively correlated with manure application rates and soil organic carbon (Table 1). Sodium ions are less tightly held to soil particles than $\mathrm{K}^{+}, \mathrm{Ca}^{2+}$ or $\mathrm{Mg}^{2+}$. Therefore, $\mathrm{Na}^{+}$is more easily leached from soil than the other cations (Marschner and Rengel, 2007), hence $\mathrm{Na}^{+}$saturation was only statistically greater in $\mathrm{M}_{4}$ than in other treatments.

Compared to the runoff and leaching of $\mathrm{N}$ and $\mathrm{P}$ in soils, which are pollutant source of underground and aboveground water, the accumulation of excessive level of $\mathrm{Ca}^{2+}, \mathrm{Mg}^{2+}$ and $\mathrm{K}^{+}$in soils, while not desirable in terms of nutrient efficiency, is unlikely to pose an environmental risk. From this point of view, manure amendment is favorable for exchangeable cation accumulation in the semi-arid grassland soils.

\subsection{Relationships of base cations with soil organic carbon and $\mathrm{pH}$}

The increase in SOC was positively correlated with the increasing rates of sheep manure application (Eq. 6), and both base cations and CEC were significantly and positively correlated with SOC (Fig. 2). Soil OM has very high base cations that originated from the presence of hydroxyl $(-\mathrm{OH})$, carboxyl $(-\mathrm{COOH})$ and phenolic groups at the surface of organic compounds and with particles of humic materials. The CEC of 
SOM ranges form $100-400 \mathrm{cmol}_{\mathcal{C}} / \mathrm{kg}$, depending on the degree of SOM composition (Foth, 1990). Degraded organic material would be expected to have a higher CEC than less degraded one, this may be attributed to the oxidative decomposition of the organic matter (Beldin et al., 2007). Moreover, calcacerous soils also derive a large proportion of their base cations and CEC from organic matter due to their low clay content and comparatively higher SOM content (Chapin et al., 2002; Beldin et al., 2007). Soils with coarser texture would have less clay and SOM and therefore have lower amounts of exchangeable cations and lower CEC (Brady and Weil, 2007). The clay content was only as low as about $3 \%$ in our study area, while the SOM content under different treatments averaged from 33.78 to $48.31 \mathrm{~g} / \mathrm{kg}$ (Fig. 2), and hence SOM was regarded as a main contributor to the increases of base cations and CEC.

Our results showed that soil $\mathrm{pH}$ increased with increasing application rates of sheep manure (Eq. 7), and both base cations and CEC were significantly and positively correlated with soil $\mathrm{pH}$ (Fig. 2). With the increase of soil $\mathrm{pH}$, the surface negative charges on clay colloids increase and the sum of positive charges of adsorbed cations increase (Foth, 1990; Renault et al., 2009). Thus, soil CEC is positively correlated with soil pH (Bortoluzzi et al., 2006). According to the Eqs. $1-5$, we could deduce that both $\mathrm{pH}$ and SOC were dominant factors contributing to the changes of base cations and CEC in soil after long-term application of sheep manure. Increasing soil $\mathrm{pH}$ has a greater effect on CEC in the SOM fraction compared to the mineral fraction. Thus, the effect of soil $\mathrm{pH}$ on CEC is greater in soils with high OM content (Havlin et al., 2004).

\subsection{Buffer effect of sheep manure application}

Soil $\mathrm{pH}$ value in treatment $\mathrm{M}_{0}$ decreased by 0.32 as compared with the initial soil $\mathrm{pH}$ before the experiment was established (Fig. 3). This decline rate of soil $\mathrm{pH}$ during the 11-year period was in accordance with Yang et al. (2012) who reported that surface soil $\mathrm{pH}$ values declined by $0.50-0.86$ in the Inner Mongolian typical steppes during the 1980s-2000s. The decline in soil $\mathrm{pH}$ was supposed mainly be attributed to atmospheric sulfur dioxide and nitrogen oxides deposition in natural grasslands (Bowman et al., 2008; Yang et al., 2012).

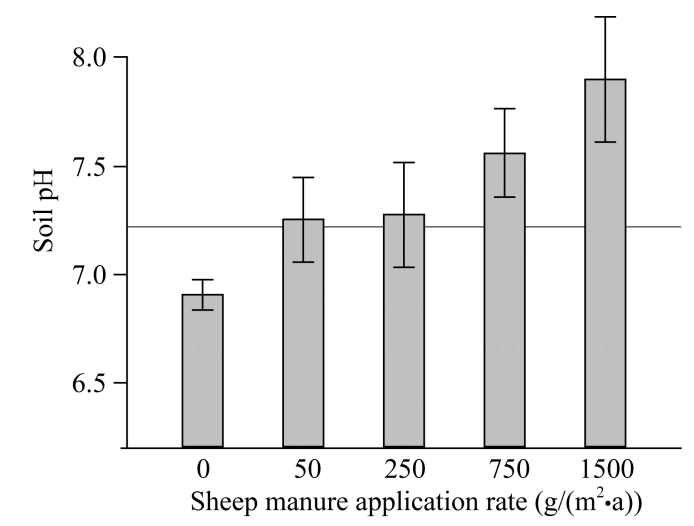

Fig. 3 Soil $\mathrm{pH}$ values at different sheep manure application rates for 11 years and a comparison with the initial soil $\mathrm{pH}(7.23)$ before the experiment was established

Sheep manure application significantly increased soil pH (Fig. 3). Soil pH in the lower application rates of manure $\left(\mathrm{M}_{1}\right.$ and $\left.\mathrm{M}_{2}\right)$ showed no significant change, as compared with the initial soil $\mathrm{pH}$ (7.23). However, both soil $\mathrm{pH}$ showed significant increases in $\mathrm{M}_{1}$ and $\mathrm{M}_{2}$ treatments, relative to $\mathrm{M}_{0}$ treatment (Fig. 3). It could be deduced that lower application of sheep manure would be enough to buffer the decrease of soil $\mathrm{pH}$ in the study region. Soil $\mathrm{pH}$ values in $\mathrm{M}_{3}$ and $\mathrm{M}_{4}$ increased by 0.65 and 0.99 , respectively, relative to $\mathrm{M}_{0}$, and increased by 0.33 and 0.67 , respectively, relative to the initial soil $\mathrm{pH}$ value (Fig. 3). Due to the significant increases in soil exchangeable base cations and CEC with heavy application of sheep manure (Fig. 1), both $M_{3}$ and $M_{4}$ treatments exhibited buffering effect on soil $\mathrm{pH}$ decline potentially occurred with atmospheric nitrogen and sulfur deposition. Moreover, both treatments had enhanced soil buffering capacity through the increases in soil CEC. The result was in accordance with a number of farmland trails. For instance, Edmeades (2003) compared the effects of manures versus fertilizers on soil properties from nine long-term field trials (20 to 120 years) over the world, and found that soil $\mathrm{pH}$ increased by $3 \%-20 \%$ in six trials under manure application. The effects of organic material addition on soil $\mathrm{pH}$ change may depend on the concentrations of excess base cations, organic anions and $\mathrm{N}$ in the materials, the initial $\mathrm{pH}$ level of the soil (Xu et al., 2006). García-Gil et al. (2004) reported that long-term amendment with municipal solid waste compost increased soil humic acid concentration and therefore increased $\mathrm{pH}$-buffer capacity. 
Although Yang et al. (2012) noted that the changes of soil $\mathrm{pH}$ showed no significant associations with soil CEC at a large scale across northern China's grasslands, our field result showed that soil $\mathrm{pH}$ was significantly increased with increasing soil CEC and base cations. In calcacerous soils, $\mathrm{pH}$ is dependent on both $\mathrm{CEC}$ and $\mathrm{CaCO}_{3}$ contents. Compared with the grasslands in northeastern China, northwestern China's grasslands have comparative higher soil $\mathrm{CaCO}_{3}$ contents and soil $\mathrm{pH}$ values (usually greater than 7.5), where $\mathrm{CaCO}_{3}$ provides more buffering capacity than CEC does. Thus, the contribution of CEC was not so significant as compared to $\mathrm{CaCO}_{3}$ at a large scale across the grasslands of northern China. In calcacerous soils, carbonate content is usually up to $5 \%$ to $10 \%$, which provides a strong acidic buffering capacity (Spiro and Stigliani, 2003). However, at least 10 $\mathrm{kg}$ of carbonates would be needed to neutralize the acidity generated by each $\mathrm{kg}$ of $\mathrm{N}$ input. The declines of soil $\mathrm{pH}$ values of about 0.3 to 0.8 were observed both in farmlands (Guo et al., 2010) and typical steppes (Yang et al., 2012) over the past two decades in calcacerous soils in northern China. The enhancement of acidic buffering capacity under sheep manure application in our study may be owing to the increases of both organic matter and base cations in soil (Fig. 2). Therefore, sheep manure application could partly buffer soil $\mathrm{pH}$ decrease in the semi-arid grassland.

\section{Conclusions}

The changes of soil organic carbon and soil $\mathrm{pH}$ are the two dominant factors contributing greatly to the increases in soil exchangeable base cations following sheep manure application in the semi-arid steppe. Exchangeable $\mathrm{Ca}^{2+}$ is the dominant cation in soil of the semi-arid grasslands. Higher sheep manure application rates could significantly increase $\mathrm{Ca}^{2+}$ exchange capacity but decrease $\mathrm{Ca}^{2+}$ saturation. The higher concentration of $\mathrm{K}^{+}$in sheep manure is regarded as the driving force to improve $\mathrm{K}^{+}$saturations with the increasing manure application rates. In brief, sheep manure application is beneficial to the increase of base cations, CEC and buffering capacity in soil, and therefore it is potentially an effective measure for the health and stability of the semi-arid grassland ecosystems in northeastern China.
At present, grassland-enclosure and grazing- forbidden policy is popularized throughout northern China's grasslands for its beneficial effects on productivity-improving and erosion-resistance. Under this practice, one of the obvious disadvantages is the depletion of mineral nutrients, especially cationic elements for higher grass output against lower or no input into these grassland ecosystems. Results from this study implicate that organic material input could help to retain cationic nutrients and buffer $\mathrm{pH}$ value decline in soils. We suggest a practical management strategy with rotation of harvesting and grazing in the temperate steppe of northeastern China, as herbivores can return manure and urine to the grassland.

\section{Acknowledgements}

This work was funded by the National Natural Science Foundation of China (41371251, 31370009) and the National Basic Research Program of China (2011CB403204). The authors thank Dr. QingMin PAN and other members of the Inner Mongolia Grassland Ecosystem Research Station of the Chinese Academy of Sciences for proving soil samples and technical assistance.

\section{References}

Beldin S I, Caldwell B A, Sollins P, et al. 2007. Cation exchange capacity of density fractions from paired conifer/grassland soils. Biology and Fertility of Soils, 43(6): 837-841.

Bortoluzzi E C, Tessier D, Rheinheimer D S, et al. 2006. The cation exchange capacity of a sandy soil in southern Brazil: an estimation of permanent and $\mathrm{pH}$-dependent charges. European Journal of Soil Science, 57(3): 356-364.

Bowman W D, Cleveland C C, Halada L, et al. 2008. Negative impact of nitrogen deposition on soil buffering capacity. Nature Geoscience, 1(11): 767-770.

Brady N C, Weil R R. 2007. The Nature and Properties of Soils. New York: Prentice Hall.

Chapin F S, Matson P A, Mooney H A. 2002. Principles of Terrestrial Ecosystem Ecology. New York: Springer-Verlag.

Chen D M, Lan Z C, Bai X, et al. 2013. Evidence that acidification-induced declines in plant diversity and productivity are mediated by changes in below-ground communities and soil properties in a semi-arid steppe. Journal of Ecology, 101(5): 1322-1334.

Chen Y L, Xu Z W, Hu H W, et al. 2013. Responses of ammonia-oxidizing bacteria and archaea to nitrogen fertilization and precipitation increment in a typical temperate steppe in Inner Mongolia. Applied Soil Ecology, 68(1): 36-45.

Diacono M, Montemurro F. 2010. Long-term effects of organic amendments on soil fertility. A review. Agronomy for Sustainable Development, 30(2): 401-422. 
Edmeades D C. 2003. The long-term effects of manures and fertilisers on soil productivity and quality: a review. Nutrient Cycling in Agroecosystems, 66(2): 165-180.

FAO. 1988. FAO-UNESCO Soil Maps of the World, Revised Legend. World Soil Resources Reports 60, FAO, Rome.

Foth H D. 1990. Soil chemistry. In Foth H D. Fundamentals of Soil Science. $8^{\text {th }}$ ed. New York: John Wiley and Sons, 164-185.

Fu M M, Jiang Y, Bai Y F, et al. 2012. Variation in soil Mn fractions as affected by long-term manure amendment using atomic absorption spectrophotometer in a typical grassland of Inner Mongolia. Spectroscopy and Spectral Analysis, 32(8): 2238-2241.

García-Gil J C, Ceppi S B, Velasco M I, et al. 2004. Long-term effects of amendment with municipal solid waste compost on the elemental and acidic functional group composition and $\mathrm{pH}$-buffer capacity of soil humic acids. Geoderma, 121(1-2): 135-142.

Guo J H, Liu X J, Zhang Y, et al. 2010. Significant acidification in major Chinese croplands. Science, 327(5968): 1008-1010.

Han X G, Owens K, Wu X B, et al. 2009. The grasslands of Inner Mongolia: a special feature. Rangeland Ecology \& Management, 62(4): 303-304.

Havlin J H, Tisdale S L, Nelson W L, et al. 2004. Soil Fertility and Fertilizers: an Introduction to Nutrient Management. $7^{\text {th }}$ eds. New Jersey: Prentice Hall.

Jiang D M, Li Q, Liu F M, et al. 2007. Vertical distribution of soil nematodes in an age sequence of Caragana microphylla plantations in the Horqin Sandy Land, Northeast China. Ecological Research, 22(1): 49-56.

Jiang Y, Zhang Y G, Liang W J, et al. 2005a. Pedogenic and anthropogenic influence on calcium and magnesium behaviors in Stagnic Anthrosols. Pedosphere, 15(3): 341-346.

Jiang Y, Liang W J, Wen D Z, et al. 2005b. Spatial heterogeneity of DTPA-extractable zinc in cultivated soils induced by city pollution and land use. Science in China: Series C, 48(Suppl. I): 82-91.

Jiang Y, Zhang Y G, Zhou D, et al. 2009. Profile distribution of micronutrients in an aquic brown soil as affected by land use. Plant Soil and Environment, 55(11): 468-476.

Lax A. 1991. Cation-exchange capacity, induced in calcareous soils by fertilization with manure. Soil Science, 151(2): 174-178.

Lieb A M, Darrouzet-Nardi A, Bowman W D. 2011. Nitrogen deposition decreases acid buffering capacity of alpine soils in the southern
Rocky Mountains. Geoderma, 164(3-4): 220-224.

Lucas R W, Klaminder J, Futter M N, et al. 2011. A meta-analysis of the effects of nitrogen additions on base cations: Implications for plants, soils, and streams. Forest Ecology and Management, 262(1): 95-104.

Marschner P, Rengel Z. 2007. Nutrient Cycling in Terrestrial Ecosystems. Berlin Heidelberg: Springer-Verlag.

Oorts K, Vanlauwe B, Merckx R. 2003. Cation exchange capacities of soil organic matter fractions in a Ferric Lixisol with different organic matter inputs. Agriculture Ecosystems \& Environment, 100(2-3): 161-171.

Renault P, Cazevieille P, Verdier J, et al. 2009. Variations in the cation exchange capacity of a ferralsol supplied with vinasse, under changing aeration conditions: Comparison between CEC measuring methods. Geoderma, 154(1-2): 101-110.

Rodella A A, Fischer K R, Alcarde J C. 1995. Cation-exchange capacity of an acid soil as influenced by different sources of organic letter. Communications in Soil Science and Plant Analysis, 26(17-18): 2961-2967.

van Erp P J. Houba V J G, van Beusichem M L. 2001. Actual cation exchange capacity of agricultural soils and its relationship with $\mathrm{pH}$ and content of organic carbon and clay. Communications in Soil Science and Plant Analysis, 32(1-2): 19-31.

Wang R Z, Dorodnikov M, Yang S, et al. 2015. Responses of enzymatic activities within soil aggregates to 9-year nitrogen and water addition in a semi-arid grassland. Soil Biology \& Biochemistry, 81(2): 159-167.

Xu J M, Tang C, Chen Z L. 2006. The role of plant residues in $\mathrm{pH}$ change of acid soils differing in initial pH. Soil Biology \& Biochemistry, 38(4): 709-719.

$\mathrm{Xu} \mathrm{Z} \mathrm{W,} \mathrm{Ren} \mathrm{H} \mathrm{Y,} \mathrm{Cai} \mathrm{J} \mathrm{P,} \mathrm{et} \mathrm{al.} \mathrm{2014.} \mathrm{Effects} \mathrm{of} \mathrm{experimen-}$ tally-enhanced precipitation and nitrogen on resistance, recovery and resilience of a semi-arid grassland after drought. Oecologia, 176: 1187-1197.

Yang Y H, Ji C J, Ma W H, et al. 2012. Significant soil acidification across northern China's grasslands during 1980s-2000s. Global Change Biology, 18(11): 2292-2300.

Zhang Y G, Xu Z W, Jiang D M, et al. 2013. Soil exchangeable base cations along a chronosequence of Caragana microphylla plantation in a semi-arid sandy land, China. Journal of Arid Land, 5(1): 42-50. 